Epistēmēs Metron Logos, Issue 4

Epistēmēs Metron Logos Journal No 4 (2020)

DOI 10.12681/eml.23779

ISSN 2585-2973

\title{
Life after COVID-19: Understanding the environment for humanity's survival and sustenance
}

Ioannis Ladas ${ }^{1}$

\begin{abstract}
The unprecedented restrictive measures imposed to stem the spread of Covid-19 disease have altered, among other things, our environmental footprint. First reports are notably encouraging, showing reductions in $\mathrm{CO}_{2}$ emissions and improvement in air quality. This essay attempts to examine whether a "positive side" could be detected in this pandemic whose impact seems cataclysmic with thousands of deaths and fears for a deep, profound global economic recession. I will cautiously argue that the longer-run environmental impact of the pandemic might be positive, though noting that a blind approval of the environmental amelioration due to the imposed restrictions entails a great risk as it may be an offshoot of a dark eco-fascist ideology promoting authoritarian and anti-democratic ideas towards improving the environment. Alongside, I will lay emphasis on the need of a new policy, i.e. a new ethical approach and deontology, oriented towards rationalizing our relationship with the natural world. At any rate, the speed of environmental deterioration does not allow a retrospective re-contemplation of the events occurring within our sociopolitical reality. It is essential that world economies prosper again without abandoning the environmental protection and that data collected during the lockdown period should serve as guidance for governments and institutions during the implementation of their recovery plans.
\end{abstract}

Keywords: Covid-19, environmental ethics, bioethics, ecofascism, political ecology, sustainability

${ }^{1}$ National and Kapodistrian University of Athens

E-mail: ioannisnladas@gmail.com 


\section{Epistēmēs Metron Logos, Issue 4}

\section{Introduction}

Since first being recorded in China in December 2019, Covid-19 (the disease caused by Severe Acute Respiratory Syndrome Coronavirus 2 (SARS-COV-2)) has been the cause of death for at least 500,000 people worldwide while the total number of confirmed cases has surpassed $11,000,000 .^{2}$ The crisis emanating from the new coronavirus has the peculiarity of directly and immediately affecting all citizens of the world in their personal and professional lives. There is no sector of public life untouched by the new reality. ${ }^{3}$ The pandemic has forced us to confront unprecedented and previously unimaginable situations. Our everyday routine is unrecognizable. Our lives have changed dramatically. Our individual freedoms have been dangerously curtailed as governments, in an effort to prevent the spread of the virus, adopted a series of severely restrictive measures including the surveillance of citizens. ${ }^{4}$ In general, the implemented measures are considered "a necessary evil" 5 , since they may negatively affect, among other things, the mental health and prosperity of citizens. ${ }^{6}$ According to studies, the restrictive measures may lead to increased suicide rates, since they negatively impact the economy, increase social isolation and reduce access

2 "Covid-19 Dashboard by the Center for Systems Science and Engineering (CSSE) at Johns Hopkins University, ” Johns Hopkins University, accessed July 6, 2020, https://coronavirus.jhu.edu/map.html.

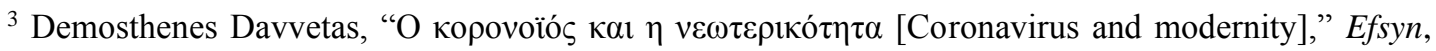
May 4, 2020, https://www.efsyn.gr/stiles/apopseis/241823_o-koronoios-kai-i-neoterikotita.

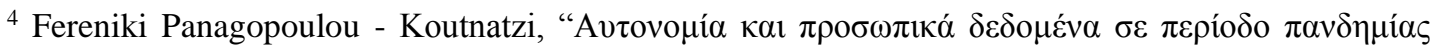
[Autonomy and personal data in a period of pandemic]," Webinar: Relationship between law and ethics in a pandemic period, May 13, 2020, https://www.eeai.gr/images/pdf/2020/perilipsi-WEBINAR-EEAI2020-NEW.pdf; "Guidelines 04/2020 on the use of location data and contact tracing tools in the context of the COVID-19 outbreak," European Data Protection Board, accessed April 21, 2020, https://edpb.europa.eu/sites/edpb/files/files/file1/edpb_guidelines_20200420_contact_tracing_covid_ with_annex_en.pdf.

${ }^{5}$ Giuseppe Lippi, Brandon M. Henry, Chiara Bovo and Fabian Sanchis-Gomar, "Health risks and potential remedies during prolonged lockdowns for coronavirus disease 2019 (COVID-19)," Diagnosis 7 (2020): 85-90, https://doi.org/10.1515/dx-2020-0041.

${ }^{6}$ Annelies Wilder-Smith, Calvin J Chiew, Vernon J Lee, "Can we contain the COVID-19 outbreak with the same measures as for SARS?," Infectious Diseases 20 (5): e102-e107, https://doi.org/10.1016/S1473-3099(20)30129-8; Martin Enserink and Kai Kupferschmidt, "With COVID-19, modeling takes on life and death importance," Science 367 (2020): 1414 1415,https://doi.org/10.1126/science.367.6485.1414-b. 


\section{Epistēmēs Metron Logos, Issue 4}

to support networks. ${ }^{7}$ Concerns have also been raised regarding increased domestic violence $^{8}$, reduced physical activity ${ }^{9}$, the risk of internet addiction and online gambling ${ }^{10}$, as well as increased alcohol consumption. ${ }^{11}$

There are thoughts that the current situation may lead to what Carl Schmitt (18881985) characterized as "State of Exception" (Ausnahmezustand). Drawing on this idea, Italian philosopher Giorgio Agamben warns that a society under permanent condition of "emergency" cannot be a free society at all. ${ }^{12}$ Danger lies in individuals or societies becoming habituated to some of these restrictions and even calling for their extension in the fear of a new severe wave of the virus that could potentially cause massive death tolls after the summer of 2020. There is also the risk that recurring crises may lead to changes that could threaten freedom and democracy, ${ }^{13}$ especially at a time where our political systems are challenged; in order to combat the pandemic a question arises: Which is more effective, democracy or autocracy? All this comes in a period when the

${ }^{7}$ Christos Melidis, Miltiadis Vantsos, "Ethical and practical considerations on cancer recommendations during COVID-19 pandemic," Molecular and Clinical Oncology 13:5, 2020, DOI:10.3892/mco.2020.2075; Mark A. Reger, Ian H. Stanley, Thomas E. Joiner, "Suicide mortality and coronavirus disease 2019-A perfect storm?," JAMA Psychiatry, April 10, 2020, https://doi.org/10.1001/jamapsychiatry.2020.1060.

${ }^{8}$ Maria Nicola, Zaid Alsafib, Catrin Sohrabic, Ahmed Kerwand, Ahmed Al-Jabird, Christos Iosifidis, Maliha Agha, Riaz Aghaf, "The socio-economic implications of the coronavirus and COVID-19 pandemic: a review," International Journal of Surgery 78 (2020): 185-193, https://doi.org/10.1016/j.ijsu.2020.04.018.

9 "Physical activity among adults in Yorkshire has fallen by a quarter since the lockdown," Yorkshire Cancer Research, accessed May 8, 2020, https://yorkshirecancerresearch.org.uk/news/physicalactivity-among-adults-in-yorkshire-has-fallen-by-a-quarter.

${ }^{10}$ Olga Kharif, "Video-game addiction poised to spread during coronavirus lockdown," Bloomberg, April 7 2020, https://www.bloomberg.com/news/articles/2020-04-07/video-game-addiction-poised-tospread-during-coronavirus-lockdown.

11 "Physical activity among adults in Yorkshire has fallen by a quarter since the lockdown," Yorkshire Cancer Research, accessed May 8, 2020, https://yorkshirecancerresearch.org.uk/news/physicalactivity-among-adults-in-yorkshire-has-fallen-by-a-quarter.

${ }^{12}$ Giorgio Agamben, State of Exception (University of Chicago Press, 2005).

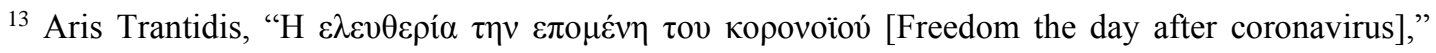
Liberal, May 15, 2020, https://www.liberal.gr/think-tanks/i-eleutheria-tin-epomeni-toukoronoiou/302367. 


\section{Epistēmēs Metron Logos, Issue 4}

Mass Media face a lack of credibility with regard to their key role in the provision of true information and the debunking of misinformation about the pandemic.

The active state response to COVID-19 was, of course, urgent and imperative, as the public health systems in almost all countries - both within and outside Europe appeared unprepared, or, even worse, inadequate to deal with this new infectious disease. ${ }^{14}$ In fact, under the particular situational pressure, medical and paramedical staff was called upon to make decisions regarding which patients would be admitted to ICU or would have access to a limited number of respirators. ${ }^{15}$ Doctors faced hard dilemmas as they were essentially forced to decide who lives and who is left to die, even though such a responsibility does not fall within their medical duties. ${ }^{16}$ The lightning-fast spread of the virus and the inadequacy of public health systems compelled the scientific community into a race for the development of safe and effective preventive vaccines or therapeutic prescription drugs for the treatment of serious complications of the coronavirus, unlike other rare or relatively new diseases in the past that were not immediately researched. However, what would have happened if the virus was only limited in the developed countries and did not massively hit the western world? In other words, what if there were no profits to be earned in resolving the problem?

Undoubtedly, the pandemic raises a number of moral issues, many of which are new while others are preexisting that should be reviewed in the light of the new data. Thus, Covid-19 was recently characterized as the "perfect moral storm". ${ }^{17}$ Despite all aforementioned matters being deemed particularly interesting, the sole objective of the

\footnotetext{
${ }^{14}$ Emanuel, Ezekiel J., Govind Persad, Ross Upshur, Beatriz Thome, Michael Parker, Aaron Glickman, Cathy Zhang, Connor Boyle, Maxwell Smith, and James P. Phillips, "Fair allocation of scarce medical resources in the time of Covid-19," New England Journal of Medicine 382 (2020): 2049-2055, https://doi.org/10.1056/NEJMsb2005114.

15 Yascha Mounk, "The extraordinary decisions facing Italian doctors," The Atlantic, March 11, 2020, https://www.theatlantic.com/ideas/archive/2020/03/who-gets-hospital-bed/607807/.

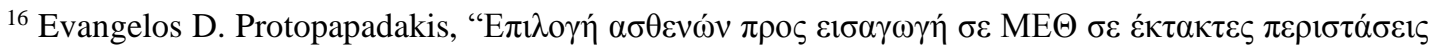
[Selection of patients for admission to ICU in emergencies]," Webinar: Relationship between law and ethics in a pandemic period, May 13, 2020, https://www.eeai.gr/images/pdf/2020/perilipsi-WEBINAREEAI-2020-NEW.pdf.

${ }^{17}$ Vicki Xafis, G. Owen Schaefer, Markus K. Labude, Yujia Zhu and Li Yan Hsu, "The Perfect Moral Storm: Diverse Ethical Considerations in the COVID-19 Pandemic," Asian Bioethics Review (12), pp. 65-83, https://doi.org/10.1007/s41649-020-00125-3.
} 


\section{Epistēmēs Metron Logos, Issue 4}

current study is to investigate the impact of lockdown on the environment and, alongside, to identify the perspectives that the scientific discussion has hitherto created for a future moral resolution of the environmental issue.

\section{Environmental impacts of lockdown}

The coronavirus pandemic has significantly impacted our environmental footprint, since the restrictive policies of governments altered energy needs worldwide. Early reports indicated that emissions of greenhouse gases have fallen sharply across continents and air quality has improved ${ }^{18}$ thanks to the shutdown of factories and the small number of operation aircrafts. ${ }^{19}$ According to published data, at the peak of the lockdown period, worldwide $\mathrm{CO}_{2}$ daily emissions were reduced by $17 \%$ compared to 2019, actually returning to the levels of 2006. In 2019, $\mathrm{CO}_{2}$ emissions averaged $100,000,000$ tons daily, mainly due to the burning of fossil fuels and cement production. At the beginning of April this year - peaking on April 7 - emissions declined to $83,000,000$ tons daily. On what concerns the cumulative change in emissions from the beginning of the year up until the end of April, it was estimated that China contributed by 242 million tons, USA by 207 million, Europe by 123

${ }^{18}$ Ruixiong Zhang, Yuzhong Zhang, Haipeng Lin, Xu Feng, Tzung-May Fu, and Yuhang Wang "NOx Emission Reduction and Recovery during COVID-19 in East China," Atmosphere. 11 (4): 433, https://doi:10.3390/atmos11040433; Jonathan Watts, Niko Kommenda, "Coronavirus pandemic leading to huge drop in air pollution," The Guardian, March 23, 2020, https://www.theguardian.com/environment/2020/mar/23/coronavirus-pandemic-leading-to-huge-dropin-air-pollution; Corinne Le Quéré, Robert B. Jackson, Matthew W. Jones, Adam J. P. Smith, Sam Abernethy, Robbie M. Andrew, Anthony J. De-Gol, David R. Willis, Yuli Shan, Josep G. Canadell, Pierre Friedlingstein, Felix Creutzig and Glen P. Peters, "Temporary reduction in daily global CO2 emissions during the COVID-19 forced confinement," Nature Climate Change (2020): 1-7. https://doi:10.1038/s41558-020-0797-x.

19 “'On average, a Jumbo Boeing 747 consumes around 150,000 litres of fuel in a 10 hrs flight. A total of around 400 billion litres of fuel is consumed annually by the commercial flights. Additionally, aircrafts fly at 8-13 km height from ground level emitting huge amount of NOx, $\mathrm{CO} 2$ and various hydrocarbons, which, indirectly, leads to the depletion of $\mathrm{O} 3$. These emissions affect radiative forcing and stratospheric ozone. The aircraft contrails mostly seen in the temperate regions cause warming of the Earth's atmosphere": Umesh Chandra Kulshrestha, "Environmental Changes during - COVID-19 Lockdown: Future Implications," Curr World Environ 2020; 15(1), DOI:http://dx.doi.org/10.12944/CWE.15.1.01. 


\section{Epistēmēs Metron Logos, Issue 4}

million and India by 98 million ${ }^{20}$. Therefore, the reduction in $\mathrm{CO}_{2}$ emissions this year is expected to be of the annual level necessary over several decades to reach the goals set by the Paris Agreement on climate change.

Having said the above, could there be a positive aspect to a pandemic that left thousands dead in 196 countries and is expected to cause one of the most severe economic crises in nearly a century, disproportionately affecting the society's most vulnerable? Although cautiously argued, the answer could be affirmative; there are two sides to every coin and the significant reduction in harmful pollutants is estimated to contribute to the salvation of thousands of human lives. Moreover, atmospheric pollution causes many more deaths than pandemics such as Covid-19, while people exposed to long-term pollution are more vulnerable to the coronavirus consequences, due to an increased probability to develop chronic respiratory problems. By calculating the reduction in atmospheric pollution and presupposing its consequent health impacts, Marshall Burke, Professor of Geology at Stanford University, deduced that in China alone "the lives of 4,000 children under 5 and 73,000 adults over 70 were saved". ${ }^{21}$ His calculations, however, are predictions and not actual measurements; moreover, his suppositions were not based on multiple factors, such as other negative

${ }^{20}$ Corinne Le Quéré, Robert B. Jackson, Matthew W. Jones, Adam J. P. Smith, Sam Abernethy, Robbie M. Andrew, Anthony J. De-Gol, David R. Willis, Yuli Shan, Josep G. Canadell, Pierre Friedlingstein, Felix Creutzig and Glen P. Peters, "Temporary reduction in daily global $\mathrm{CO} 2$ emissions during the COVID-19 forced confinement," Nature Climate Change (2020): 1-7. https://doi:10.1038/s41558-0200797-x.

${ }^{21}$ Marshall Burke measured the PM2.5 levels in the atmosphere, which are suspended particles and comprise a significant parameter of atmospheric pollution, impaction health as well as the environment (climate change, reduced visibility, erosion of monuments). 


\section{Epistēmēs Metron Logos, Issue 4}

effects of lockdown on health. ${ }^{22}$ Nonetheless, they comprise a useful reminder of the hidden impacts of the modern lifestyle on our health. ${ }^{23}$

In relevance to the environmental impacts of the lockdown, it is worth mentioning that the benefits from the reduced human activity extend, globally, to the wildlife. Animals have been returning to places that had been inaccessible due to human activity. We recently witnessed the canals of Venice being so clean that jellyfish were spotted swimming; ${ }^{24}$ in Thailand's beaches, the largest increase in births of sea turtles in the last two decades was observed. ${ }^{25}$ Furthermore, fish biomass could increase due to the steep reduction in fishing. ${ }^{26}$ Of course, long-term human absence may not be considered a positive contribution. If a species claims a new geographical area, it could lead to the extinction of other species, leading to ecosystem disruptions. ${ }^{27}$

Undoubtedly, the worldwide lockdown has had its own profound impact. It is still early to evaluate the environmental implications of the restrictions, but many are

${ }^{22}$ In the same context, Dr. Klea Kastougianni, Professor of Biostatistics and Epidemiology in the National and Kapodistrian University of Athens expressed her confidence that certain deaths and health problems have been prevented due to the short-term reduction in atmospheric pollution. Elias

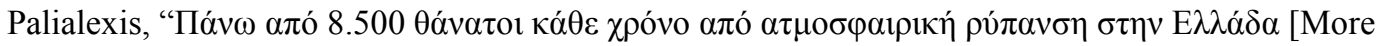
than 8,500 deaths a year in Greece by air pollution]," Athens News Agency - Macedonian News Agency, May 31, 2020, https://www.amna.gr/home/article/462016/Ereuna-EKPAA--sto-APE-MPEPano-apo-8500-thanatoi-kathe-chrono-apo-atmosfairiki-rupansi-stin-Ellada.

23 Jeff McMahon, "Study: Coronavirus Lockdown Likely Saved 77,000 Lives In China Just By Reducing Pollution," Forbes, March 2020, https://www.forbes.com/sites/jeffmcmahon/2020/03/16/coronavirus-lockdown-may-have-saved77000-lives-in-china-just-from-pollution-reduction/\#2e50610c34fe.

24 "Jellyfish seem swimming in Venice's canals," Cnn, April 23, 2020, https://edition.cnn.com/travel/article/jellyfish-venice/index.html.

25 Jack Guy and Carly Walsh, "Sea turtles thriving in Thailand after beach closures," Cnn, April 20, 2020, https://edition.cnn.com/travel/article/thailand-sea-turtles-coronavirus-scli-intl-scn/index.html.

26 Tristram Korten, "With Boats Stuck in Harbor Because of COVID-19, Will Fish Bounce Back?," Smithsonian Magazine, April 24, 2020, https://www.smithsonianmag.com/science-nature/fish-stopcovid-19-180974623/.

${ }^{27}$ Kieron Monks, "Rays, sharks, and dolphins enjoy new freedom as humans retreat from the oceans," Cnn, April 29, 2020, https://edition.cnn.com/travel/article/marine-conservation-uae-spcintl/index.html. 


\section{Epistēmēs Metron Logos, Issue 4}

optimistic that future data will show that our home-life has become "greener". ${ }^{28}$ Nonetheless, the greatest public health crisis in modern times may also have undesirable environmental consequences. Activists and organizations - mainly through online means in deference to the restrictive measures ${ }^{29}$ - express concern for the tons of plastic products and the use of chemicals applied for disinfections for protection from the virus. ${ }^{30}$ Governments and citizens are struggling to increase their reserve stocks of surgical masks, gloves and protective gear in general. All this plastic, however, has to end "somewhere". Environmental champions fear that oceans will not remain unaffected. The Oceans Campaign Director for Greenpeace USA, John Hacevar notes: "Right outside my house there are discarded masks and gloves all over the neighborhood. It has been raining for two days, and all that quickly ends up in the sewers. Here in Washington they end up in Anacostia river and then in the Atlantic ocean". ${ }^{31}$ Furthermore, an increase in illegal activities has been noted, such as the deforestation of the Amazon tropical forest ${ }^{32}$, poaching in Africa ${ }^{33}$ and illegal logging

${ }^{28}$ Rachel Moss, "Is The Coronavirus Lockdown Good For The Planet?," HuffPost, April 22, 2020,
https://www.huffingtonpost.co.uk/entry/coronarivus-lockdown-planet-climate-change-
environment_uk_5e9ed8cbc5b6b2e5b837e72c?fbclid=IwAR38SGas95jar2Ys4ZKWVJcr7ATCbRsW pVyIENCtfsWny4f-BU20Zju1910.

29 "Environmental activism goes digital in lockdown - but could it change the movement for good?" The Conversation, May 7, 2020, https://theconversation.com/environmental-activism-goes-digital-inlockdown-but-could-it-change-the-movement-for-good-137203.

30 "Discarded coronavirus masks clutter Hong Kong's beaches, trails," Reuters, March 21, 2020, https://www.reuters.com/article/us-health-coronavirus-hongkong-environme/discarded-coronavirusmasks-clutter-hong-kongs-beaches-trails-idUSKBN20Z0PP.

31 Rob Picheta, "Coronavirus is causing a flurry of plastic waste. Campaigners fear it may be permanent” CNN, May 4, 2020, https://edition.cnn.com/2020/05/04/world/coronavirus-plastic-wastepollution-intl/index.html.

32 Evan Simon and Aicha El Hammar Castano "Deforestation of Amazon rainforest accelerates amid COVID-19 pandemic," ABC News, May 6, 2020, https://abcnews.go.com/International/deforestationamazon-rainforest-accelerates-amid-covid-19-pandemic/story?id=70526188; Jamie Roberton and Lorand Bodo, "Deforestation of the Amazon has soared under cover of the coronavirus," NBC News, May 11, 2020, https://www.nbcnews.com/science/environment/deforestation-amazon-has-soaredunder-cover-coronavirus-n1204451.

${ }^{33}$ Meredith Deliso, "Conservationists fear African animal poaching will increase during COVID-19 pandemic," $A B C$ News, April 14, 2020, https://abcnews.go.com/International/conservationists-fearafrican-animal-poaching-increase-covid-19/story?id=70118142; Emma Newburger, "Filthy bloody business: Poachers kill more animals as coronavirus crushes tourism to Africa," CNBC, April 24, 2020, 


\section{Epistēmēs Metron Logos, Issue 4}

in Tunisia. ${ }^{34}$ It is also expected that in African countries there will be a surge in the demand for "high value products" such as rhinoceros horn and ivory. ${ }^{35}$ To all this we must add that the economic repercussions of lockdown could mean cutting back investments in green energy technologies. ${ }^{36}$ For example, a number of governments announced that they are lowering environmental standards ${ }^{37}$, suspending environmental monitoring requirements, reducing environmental enforcement, and restricting public participation ${ }^{38}$, at a time when the 2020 United Nations Conference on Climatic Change has been postponed for 2021. ${ }^{39}$ With the 2020 coronavirus outbreak spreading rapidly within the European Union, the focus on the European

https://www.cnbc.com/2020/04/24/coronavirus-poachers-kill-more-animals-as-tourism-to-africaplummets.html.

${ }^{34}$ Layli Foroudi, "Under the cover of lockdown, illegal logging surges in Tunisia," Thomson Reuters Foundation News, May 1, 2020, https://news.trust.org/item/20200501041915-qph07/.

35 Meredith Deliso, "Conservationists fear African animal poaching will increase during COVID-19 pandemic," ABC News, April 14, 2020, https://abcnews.go.com/International/conservationists-fearafrican-animal-poaching-increase-covid-19/story?id=70118142; Emma Newburger, "Filthy bloody business:' Poachers kill more animals as coronavirus crushes tourism to Africa," CNBC, April 24, 2020, https://www.cnbc.com/2020/04/24/coronavirus-poachers-kill-more-animals-as-tourism-to-africaplummets.html.

36 Emma Newburger, "Coronavirus could weaken climate change action and hit clean energy investment, researchers warn," CNBC, March 13, 2020, https://www.cnbc.com/2020/03/13/coronavirus-could-weaken-climate-change-action-hit-cleanenergy.html.

37 The United States' Trump administration suspended the enforcement of some environmental protection laws via the Environmental Protection Agency (EPA) during the pandemic. This allows polluters to ignore some environmental laws if they can claim that these violations were caused by the pandemic: Oliver Milman and Emily Holden, "Trump administration allows companies to break pollution laws during coronavirus pandemic," The Guardian, March 27, 2020,

https://www.theguardian.com/environment/2020/mar/27/trump-pollution-laws-epa-allows-companiespollute-without-penalty-during-coronavirus.

${ }^{38}$ David Boyd, "COVID-19: 'Not an excuse' to roll back environmental protection and enforcement," June

1 , 2020 , https://www.ohchr.org/EN/NewsEvents/Pages/DisplayNews.aspx?NewsID=25794\&LangID=E. Dr. David R. Boyd was appointed as the UN Special Rapporteur on human rights and the environment for a three-year term commencing August 1, 2018.

39 This Conference was crucial as nations were scheduled to submit enhanced nationally determined contributions to the Paris Agreement. 


\section{Epistēmēs Metron Logos, Issue 4}

Green Deal has been diminished. Some have suggested either a yearly pause or even a complete discontinuation of the deal. Many believe the current main focus of the European Union's policymaking process should be the immediate, shorter-term crisis rather than climate change. ${ }^{40}$

\section{The danger of downgrading human life in favor of environmental progress}

Blind approval of the environmental progress caused by the lockdown restrictions poses a great risk since sometimes there is an underlying opinion that the world would be a better place without us, or more often, without some of us. For example, there are messages posted in social media networks, stating that "we" the people are "bad news for the planet". A characteristic example is a post referring to the drop in atmospheric and water pollution wherein it is emphasized that "the corona-virus is the Earth's vaccine" and "we are the virus". This post received around 300,000 "likes" and has been reposted more than 70,000 times in less than two weeks. Be that as it may, the trivialization or even the encouragement of human death and suffering so long as it contributes to the salvation of environment is an example of a dark ideology, an ecofascism ${ }^{41}$ promoting autocratic and fascist ideologies for the environmental good. ${ }^{42}$ Moreover, the greatest failure of eco-fascism is that while allegedly aiming at the rationalization of stable environmental ethics, it neglects the essence as well as the mission of ethics. Ethics "is but a convention, to which moral subjects accede with the aim to promote their best interests". Ethics' ultimate goal can only be the promotion of the quality of human life and the creation of an environment wherein humans are

\footnotetext{
${ }^{40}$ Milan Elkerbout, Christian Egenhofer, Jorge Núñez Ferrer, Mihnea Catuti, Irina Kustova, Vasileios Rizos, "The European Green Deal after Corona: Implications for EU climate policy," CEPS, March 31, 2020, https://www.ceps.eu/ceps-publications/the-european-green-deal-after-corona/.

${ }^{41}$ Michael E. Zimmerman defines "ecofascism" as "a totalitarian government that requires individuals to sacrifice their interests to the well-being of the 'land', understood as the splendid web of life, or the organic whole of nature, including peoples and their states". Michael Zimmerman, "Ecofascism," in Encyclopedia of Religion and Nature, ed. Bron Taylor (London: Continuum 2008) 531-532.

${ }^{42}$ Sierra Garcia, "We're the virus': The pandemic is bringing out environmentalism's dark side," Grist, March 30, 2020, https://grist.org/climate/were-the-virus-the-pandemic-is-bringing-outenvironmentalisms-dark-side/.
} 


\section{Epistēmēs Metron Logos, Issue 4}

worth living. An ethic that promotes the downgrading or destruction of human life in favor of all the other creatures is not a human ethics. ${ }^{43}$

\section{Towards a rationalization of our relationship with the environment}

The anxious pursuit of financial enlargement as the single goal of development has driven our cognitive - scientific potential to an impasse, rendering us incompetent to manage our achieved progress. Our relationship with the natural environment became so antagonistic that more people are now displaced due to global warming than wars, giving rise to a population of environmental refugees and immigrants. ${ }^{44}$ It is for this reason that Professor Tasios noted that the "development" promised by the "modern" way of life is actually deceitful. On the contrary, in order to realize such a development, a four-pronged strategy is necessary, whereby environmental, economic, social and cultural sustainability are pursued equivalently. To underpin

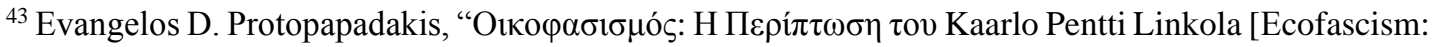
The case of Kaarlo Pentti Linkola]," in Enviroment - Society - Ethics, ed. Elena Papanikolaou (Athens: Procceedings of the 2nd International Meeting on Environmental Ethics, 2010), 93.

44 Konstantina Vratsanou, Hara Giannakopoulou, Constantina Skanavis, Valentina Plaka,

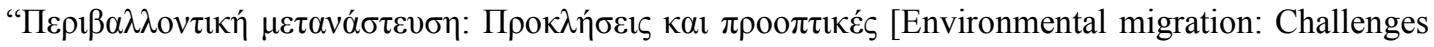
and perspectives]," in Environmental Sociology, ed. Evangelos Manolas (Athens: Gutenberg, 2017), 67-92.
} 


\section{Epistēmēs Metron Logos, Issue 4}

such an approach, a new Policy, or rather a new Ethics, ${ }^{45}$ is required, capable of managing and integrating the above components. ${ }^{46}$

As of the last decades of the $20^{\text {th }}$ century there has been increasing interest in the human-nature relationship and the effects of human interference on the physical environment. Proposed solutions promote a new orientation or a new "morality" that acknowledges an "intrinsic value" to the natural world. Such solutions are, for example, the "Land Ethics" of Aldo Leopold (1887-1948), that demonstrates people belonging to the biotic community (the land) and not owning it; the deeply ecological stance expressed by Norwegian philosopher Arne Naess (1912-2009), advocating for forms of identification with the non-human world; the ecological feminism, which rejects as patriarchal the prevailing attitude with regard to the natural world. These theories have not been without reasonable criticism. Consequently, it is imperative to investigate whether and to what degree they comprise cohesive and firm moral theories, i.e. whether they can yield effective solution to the already exceedingly acute environmental problem, or, at least, lay the groundwork for the evolution of

\footnotetext{
${ }^{45}$ Perhaps the manner in which Kant perceives moral duty, freedom, dignity and autonomy of the moral person is sufficient in indicating what we ought to do and what to avoid concerning our relationship with the natural world surrounding us. It is the opinion of Professor Protopapadakis that the Kantian ethics suffices to "convince us that it is our duty to abstain from all deliberate acts which would bring about the deterioration or even destruction of the natural world, since it dictates the simple truth that: if man, by reason and deliberation destroys the natural environment, he acts in a manner irrational and inappropriate to human nature". See Evangelos D. Protopapadakis, "Climate Change: A Challenge for Ethics," in English through Climate Change, ed. Walter Leal Filho and Evangelos Manolas (Orestiada: Deparment's of Forestry and Management of the Environment and Natural Resources Democritus

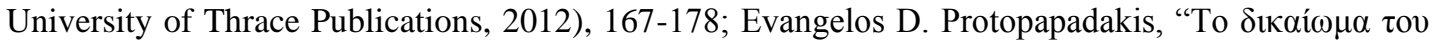

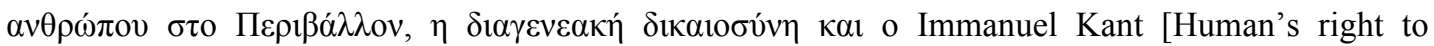
environmental, Intergenerational equity and Immanuel Kant]," in International Environmental Policy, ed. Evangelos Manolas, Evangelos Protopapadakis and Georgios Tsantopoulos (Orestiada: Deparment's of Forestry and Management of the Environment and Natural Resources Democritus University of Thrace Publications, 2013), 182-190.

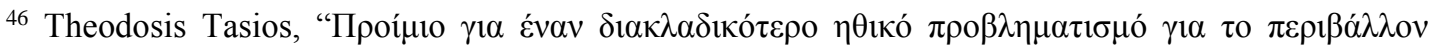
[Prelude for a more interdisciplinary ethical concern for the environment]," in Environmental Ethics Challenges and Perspectives, ed. Evangelos Protopapadakis and Evangelos Manolas (Orestiada: Deparment's of Forestry and Management of the Environment and Natural Resources Democritus University of Thrace Publications, 2012), 195-205.
} 


\section{Epistēmēs Metron Logos, Issue 4}

environmental ethics. ${ }^{47}$ Evangelos Protopapadakis, Head of the Greek Unit of the UNESCO Chair in Bioethics (Haifa), for example, claims that Leopold's Land Ethics does not comprise a cohesive and integrated system, while at the same time it incites a peculiar moral absolutism. Within this framework he notes that the central concepts of this theory lack clear demarcation and that the reasoning has no probative value while at the same time such positions entail a high potential risk. Nevertheless, regarding the fertility of Leopold's theory, he seems convinced that beyond the stimulus it has hitherto offered to environmental ethics it can also serve in the future as a springboard for evolution and progress, precisely because as a point of intense objections it lends itself to creative philosophical dialogue. ${ }^{48}$

Regardless if only mankind or nature as a whole is the ultimate goal of environmental protection, at the core of environmental ethics lies the effort to express a basis of interest in the natural world. Environmental ethics investigates the prospects of a sustainable relationship between economic and ecological systems, and seeks for indications of this relationship in reference to social justice and political institutions. ${ }^{49}$ Current environmental problems have accumulated, especially over the last decades, and, among other factors, result from a lack of both environmental ethics and

${ }^{47}$ Evangelos D. Protopapadakis, “'Supernatural Will' and 'Organic Unity in Process': From Spinoza's Naturalistic Pantheism to Arne Naess' New Age 'Ecosophy T' and Environmental Ethics,' in Studies on Supernaturalism, ed. George Arabatzis (Berlin: Logos Verlag, 2009), 173-193; Evangelos D. Protopapadakis, "The stoic notion of cosmic sympathy in contemporary environmental ethics," in Антика, савремени свет и рецепција античке културе (Belgrade: Друштво за античке студије

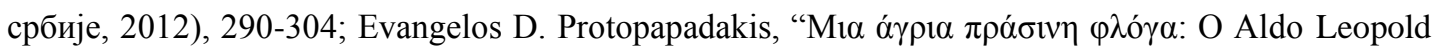
$\kappa \alpha \imath \eta \eta \theta$ - Challenges and Perspectives, ed. Evangelos Protopapadakis and Evangelos Manolas (Orestiada: Deparment's of Forestry and Management of the Environment and Natural Resources Democritus University of Thrace Publications, 2012), 128.

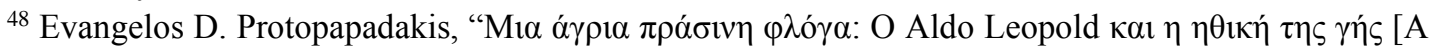
wild green flame: Aldo Leopold and the land ethics]," in Environmental Ethics - Challenges and Perspectives, ed. Evangelos Protopapadakis and Evangelos Manolas (Orestiada: Deparment's of Forestry and Management of the Environment and Natural Resources Democritus University of Thrace Publications, 2012), 128.

49 Robert Audi, ed., The Cambridge Dictionary of Philosophy (Cambridge: Cambridge University Press, 2015). 


\section{Epistēmēs Metron Logos, Issue 4}

environmental education. ${ }^{50}$ The rate of natural degradation compels citizen participation in the environmental decision-making process. ${ }^{51}$ In this respect, citizens must acquire the capacity to understand the environmental issues, to identify their origins and to evaluate potential solutions while also demonstrating participatory skills. ${ }^{52}$ If we wish to ensure the longevity of economic activity we must strive for its coexistence alongside an environmental sustainability. ${ }^{53}$

\section{Conclusion}

The Covid-19 crisis will eventually be overcome and, looking ahead, the impending global recession should be seen as an unmissable opportunity to kickstart a new equitable economy and a more ethical financial system. Our economies must prosper again while rebalancing our relationship with nature. Data collected by governments during the lockdown period are great tools to navigate the recovery plans. Investments should be environmentally responsible, supporting the transformation to a future of green tech, clean energy and agroecology. ${ }^{54}$ Henceforth, retrospective reflection on

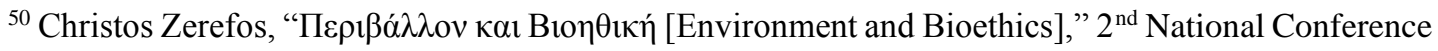
Greece-Europe 2020: Education, Lifelong Learning, Research, New Technologies and Innovation: Lamia, 2018, https://eproceedings.epublishing.ekt.gr/index.php/inoek/article/view/2441/2265.

51 "All model projections indicate that Earth will continue to warm considerably more over the next few decades to centuries. If there were no technological or policy changes to reduce emission trends from their current trajectory, then further globally-averaged warming of 2.6 to $4.8^{\circ} \mathrm{C}$ ( 4.7 to $8.6{ }^{\circ} \mathrm{F}$ ) in addition to that which has already occurred would be expected during the 21 st century". "The basics of climate change," The Royal Society, accessed May 1, 2020. https://royalsociety.org/topicspolicy/projects/climate-change-evidence-causes/basics-of-climate-change/. Xafis, Vicki. Schaefer, G. Owen. Labude, Markus K. Zhu, Yujia. and Hsu, Li Yan. "The Perfect Moral Storm: Diverse Ethical Considerations in the COVID-19 Pandemic." Asian Bioethics Review (12), pp. 65-83, https://doi.org/10.1007/s41649-020-00125-3.

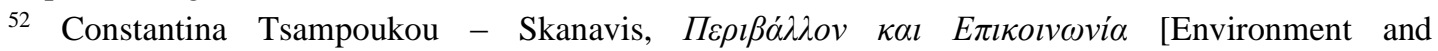
Communication] (Athens: Kaleidoscope publications, 2004) 13-14.

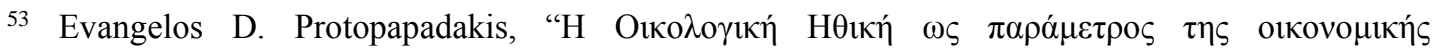
$\delta \rho \alpha \sigma \tau \eta \rho t o ́ \tau \eta \tau \varsigma \varsigma$ [Ecological Ethics as a parameter of economic activity]," in Business Ethics, ed. S. A. Antoniou (Athens-Komotini: Sakkoulas Publications, 2008), 313.

${ }^{54}$ Anna Turns, "Five eco lessons I've learnt from lockdown," Wicked Leeks, May 15, 2020, https://wickedleeks.riverford.co.uk/opinion/environment-ethics-local-sourcing-food-waste/five-ecolessons-ive-learnt-lockdown. 


\section{Epistēmēs Metron Logos, Issue 4}

devastating events in the socio-political reality or passive acceptance should not be an option. It is important that, as Dr. Maria Neira of the World Health Organization (WHO) accurately noted, "when we at last take off the mask, let's keep on breathing clean air". The protection of the planet as well as of our daily lives is everyone's both a right and a duty. A radical change in our mentality and in the manner in which we have been realizing our desires are called for. ${ }^{55}$

\section{References}

Agamben, Giorgio. State of Exception. Chicago: University Press, 2005.

Elkerbout, Milan. Egenhofer, Christian. Ferrer, Jorge Núñez. Catuti, Mihnea. Kustova, Irina. Rizos, Vasileios. "The European Green Deal after Corona: Implications for EU climate policy." CEPS, March 31, 2020. https://www.ceps.eu/ceps-publications/the-european-green-deal-after-corona/.

Enserink, Martin and Kupferschmidt, Kai. "With COVID-19, modeling takes on life and death importance." Science $367 \quad$ (2020): $1414 \quad 1415$. https://doi.org/10.1126/science.367.6485.1414-b.

European Data Protection Board, "Guidelines 04/2020 on the use of location data and contact tracing tools in the context of the COVID-19 outbreak." Accessed April 21, 2020.

https://edpb.europa.eu/sites/edpb/files/files/file1/edpb_guidelines_20200420_contact _tracing_covid_with_annex_en.pdf.

Ezekiel, Emanuel. Persad, Govind. Upshur, Ross. Thome, Beatriz. Parker, Michael. Glickman, Aaron. Zhang, Cathy. Boyle, Connor. Smith, Maxwell. and Phillips, James. "Fair allocation of scarce medical resources in the time of Covid-19." New England Journal of Medicine $382 \quad$ (2020): $2049-2055$. https://doi.org/10.1056/NEJMsb2005114.

Foroudi, Layli. "Under the cover of lockdown, illegal logging surges in Tunisia." Thomson Reuters Foundation News, May 1, 2020. https://news.trust.org/item/20200501041915-qph07/.

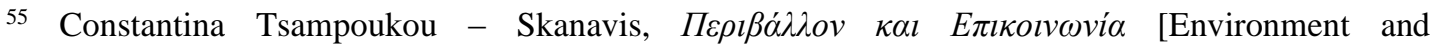
Communication] (Athens: Kaleidoscope publications, 2004) 13-14. 


\section{Epistēmēs Metron Logos, Issue 4}

Garcia, Sierra. "We're the virus': The pandemic is bringing out environmentalism's dark side", Grist, March 30, 2020. https://grist.org/climate/werethe-virus-the-pandemic-is-bringing-out-environmentalisms-dark-side/.

Kharif, Olga. "Video-game addiction poised to spread during coronavirus lockdown." Bloomberg, $\quad$ April $\quad 720$. https://www.bloomberg.com/news/articles/2020-04-07/video-game-addictionpoised-to-spread-during-coronavirus-lockdown.

Korten, Tristram. "With Boats Stuck in Harbor Because of COVID-19, Will Fish Bounce Back?." Smithsonian Magazine, April 24, 2020. https://www.smithsonianmag.com/science-nature/fish-stop-covid-19-180974623/.

Kulshrestha, Umesh Chandra. "Environmental Changes during - COVID-19 Lockdown: Future Implications." Curr World Environ 2020; 15(1). DOI:http://dx.doi.org/10.12944/CWE.15.1.01.

Le Quéré, Corinne. Jackson, Robert. Jones, Matthew. Smith, Adam. Abernethy, Sam. Andrew, Robbie. J. De-Gol, Anthony. Willis, David. Shan, Yuli. Canadell, Josep. Friedlingstein, Pierre. Creutzig, Felix. and Peters, Glen. "Temporary reduction in daily global CO2 emissions during the COVID-19 forced confinement." Nature Climate Change (2020): 1-7. https://doi:10.1038/s41558-020-0797-x.

Lippi, Giuseppe. Henry, Brandon. Bovo, Chiara. and Sanchis-Gomar, Fabian. "Health risks and potential remedies during prolonged lockdowns for coronavirus disease 2019 (COVID-19)." Diagnosis 7 (2020): 85-90. https://doi.org/10.1515/dx2020-0041.

McMahon, Jeff. "Study: Coronavirus Lockdown Likely Saved 77,000 Lives In China Just By Reducing Pollution." Forbes, March 16, 2020. https://www.forbes.com/sites/jeffmcmahon/2020/03/16/coronavirus-lockdown-mayhave-saved-77000-lives-in-china-just-from-pollution-reduction/\#2e50610c34fe.

Melidis, Christos. Vantsos, Miltiadis. "Ethical and practical considerations on cancer recommendations during COVID-19 pandemic." Molecular and Clinical Oncology 13:5, 2020, DOI:10.3892/mco.2020.2075.

Milman, Oliver and Holden, Emily. "Trump administration allows companies to break pollution laws during coronavirus pandemic.” The Guardian, March 27, 2020. 


\section{Epistēmēs Metron Logos, Issue 4}

https://www.theguardian.com/environment/2020/mar/27/trump-pollution-laws-epaallows-companies-pollute-without-penalty-during-coronavirus.

Moss, Rachel. "Is The Coronavirus Lockdown Good For The Planet?.", HuffPost, April 22, 2020. https://www.huffingtonpost.co.uk/entry/coronarivus-lockdownplanet-climate-change-

environment_uk_5e9ed8cbc5b6b2e5b837e72c?fbclid=IwAR38SGas95jar2Ys4ZKW VJcr7ATCbRsWpVyIENCtfsWny4f-BU20Zju1910.

Mounk, Yascha. "The extraordinary decisions facing Italian doctors." The Atlantic, March 11, 2020. https://www.theatlantic.com/ideas/archive/2020/03/who-getshospital-bed/607807/.

Newburger, Emma. "Coronavirus could weaken climate change action and hit clean energy investment, researchers warn." CNBC, March 13, 2020. https://www.cnbc.com/2020/03/13/coronavirus-could-weaken-climate-changeaction-hit-clean-energy.html.

Newburger, Emma. "Filthy bloody business: Poachers kill more animals as coronavirus crushes tourism to Africa." CNBC, April 24, 2020. https://www.cnbc.com/2020/04/24/coronavirus-poachers-kill-more-animals-astourism-to-africa-plummets.html.

Nicola, Maria. Alsafib, Zaid. Sohrabic, Catrin. Kerwand, Ahmed. Al-Jabird, Ahmed. Iosifidis, Christos. Agha, Maliha. Aghaf, Riaz. "The socio-economic implications of the coronavirus and COVID-19 pandemic: a review." International Journal of Surgery 78: 185-193. https://doi.org/10.1016/j.ijsu.2020.04.018.

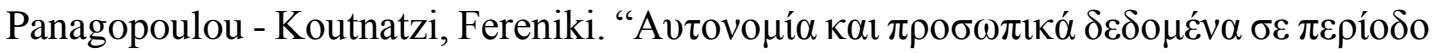
$\pi \alpha v \delta \eta \mu i \boldsymbol{i}_{\varsigma}$ [Autonomy and personal data in a period of pandemic]." Webinar: Relationship between law and ethics in a pandemic period, May 13, 2020. https://www.eeai.gr/images/pdf/2020/perilipsi-WEBINAR-EEAI-2020-NEW.pdf.

Picheta, Rob. "Coronavirus is causing a flurry of plastic waste. Campaigners fear it may be permanent." CNN, May 4, 2020. https://edition.cnn.com/2020/05/04/world/coronavirus-plastic-waste-pollutionintl/index.html. 


\section{Epistēmēs Metron Logos, Issue 4}

Protopapadakis, Evangelos. “'Supernatural Will' and 'Organic Unity in Process': From Spinoza's Naturalistic Pantheism to Arne Naess' New Age 'Ecosophy T' and Environmental Ethics." In Studies on Supernaturalism, edited by George Arabatzis, 173-193. Berlin: Logos Verlag, 2009.

Protopapadakis, Evangelos. "Earth as a Life-raft and Ethics as the Raft's Axe." In From Humanism to Meta-,Post- and Transhumanism?, edited by Irina Deretić and Stefan Lorenz Sorgner, 227 - 241. Frankfurt: Peter Lang Edition, 2016.

Protopapadakis, Evangelos. "The stoic notion of cosmic sympathy in contemporary environmental ethics." In Антика, савремени свет и рецепција античке културе, 290-304. Belgrade: Друштво за античке студије србије, 2012.

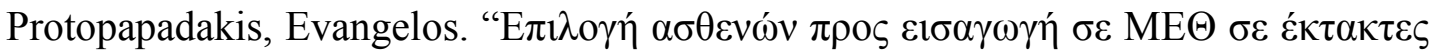
$\pi \varepsilon \rho ı \tau \tau \alpha ́ \sigma \varepsilon ı \varsigma$ [Selection of patients for admission to ICU in emergencies]." Webinar: Relationship between law and ethics in a pandemic period, May 13, 2020. https://www.eeai.gr/images/pdf/2020/perilipsi-WEBINAR-EEAI-2020-NEW.pdf.

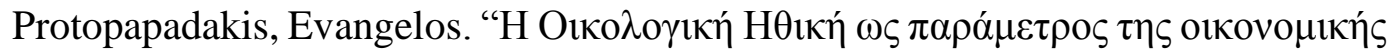
$\delta \rho \alpha \sigma \tau \eta \rho$ เó $\rceil \tau \alpha_{\varsigma}$ [Ecological Ethics as a parameter of economic activity]." In Business Ethics, edited by S. A. Antoniou, 301-316. Athens-Komotini: Sakkoulas Publications, 2008.

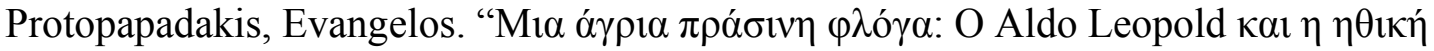

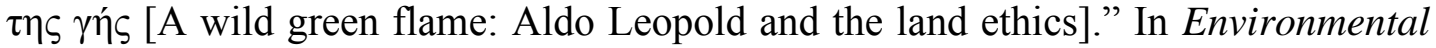
Ethics - Challenges and Perspectives, edited by Evangelos Protopapadakis and Evangelos Manolas, 127-141. Orestiada: Deparment's of Forestry and Management of the Environment and Natural Resources Democritus University of Thrace Publications, 2012.

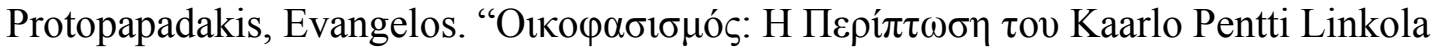
[Ecofascism: The case of Kaarlo Pentti Linkola].” In Enviroment - Society - Ethics, edited by Elena Papanikolaou, 74-96. Athens: Procceedings of the $2^{\text {nd }}$ International Meeting on Environmental Ethics, 2010.

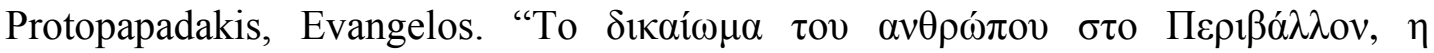

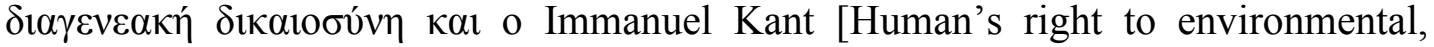
Intergenerational equity and Immanuel Kant]." In International Environmental Policy, edited by Evangelos Manolas, Evangelos Protopapadakis and Georgios Tsantopoulos, 


\section{Epistēmēs Metron Logos, Issue 4}

182-190. Orestiada: Deparment's of Forestry and Management of the Environment and Natural Resources Democritus University of Thrace Publications, 2013.

Protopapadakis, Evangelos. "Climate Change: A Challenge for Ethics." In English through Climate Change, edited by Walter Leal Filho and Evangelos Manolas, 167178. Orestiada: Deparment's of Forestry and Management of the Environment and Natural Resources Democritus University of Thrace Publications, 2012.

Reger, Mark. Stanley, Ian. Joiner, Thomas. "Suicide mortality and coronavirus disease 2019-A perfect storm?." JAMA Psychiatry, April 10, 2020. https://doi.org/10.1001/jamapsychiatry.2020.1060.

Reuters. "Discarded coronavirus masks clutter Hong Kong's beaches, trails." March 21, 2020. https://www.reuters.com/article/us-health-coronavirus-hongkongenvironme/discarded-coronavirus-masks-clutter-hong-kongs-beaches-trailsidUSKBN20Z0PP.

Roberton, Jamie and Bodo, Lorand. "Deforestation of the Amazon has soared under cover of the coronavirus." NBC News, May 11, 2020. https://www.nbcnews.com/science/environment/deforestation-amazon-has-soaredunder-cover-coronavirus-n1204451.

Simon, Evan and Castano, Aicha El Hammar. "Deforestation of Amazon rainforest accelerates amid COVID-19 pandemic." $A B C$ News, May 6, 2020. https://abcnews.go.com/International/deforestation-amazon-rainforest-acceleratesamid-covid-19-pandemic/story?id=70526188.

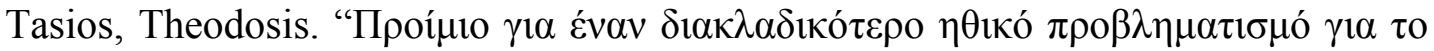
$\pi \varepsilon \rho 1 \beta \alpha ́ \lambda \lambda$ ov [Prelude for a more interdisciplinary ethical concern for the environment]." In Environmental Ethics - Challenges and Perspectives, edited by Evangelos Protopapadakis and Evangelos Manolas, 195-205. Orestiada: Deparment's of Forestry and Management of the Environment and Natural Resources Democritus University of Thrace Publications, 2012.

The Conversation. "Environmental activism goes digital in lockdown - but could it change the movement for good?." May 7, 2020. https://theconversation.com/environmental-activism-goes-digital-in-lockdown-butcould-it-change-the-movement-for-good-137203. 


\section{Epistēmēs Metron Logos, Issue 4}

Trantidis, Aris. "Freedom the day after coronavirus." Liberal, May 15, 2020. https://www.liberal.gr/think-tanks/i-eleutheria-tin-epomeni-tou-koronoiou/302367.

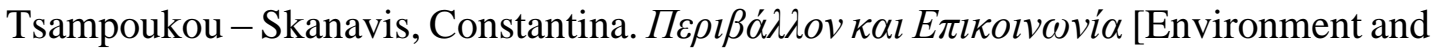
Communication]. Athens: Kaleidoscope publications, 2004.

Turns, Anna. "Five eco lessons I've learnt from lockdown." Wicked Leeks, May 15, 2020. https://wickedleeks.riverford.co.uk/opinion/environment-ethics-localsourcing-food-waste/five-eco-lessons-ive-learnt-lockdown.

Vratsanou, Konstantina. Giannakopoulou, Hara. Skanavis, Constantina. and Plaka,

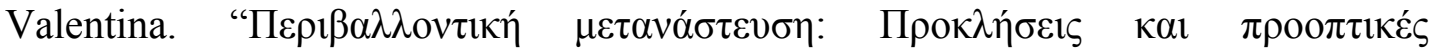
[Environmental migration: Challenges and perspectives]." In Environmental Sociology, edited by Evangelos Manolas, 67-92. Athens: Gutenberg, 2017.

Watts, Jonathan. Kommenda, Niko. "Coronavirus pandemic leading to huge drop in air pollution." The Guardian, March 23, 2020. https://www.theguardian.com/environment/2020/mar/23/coronavirus-pandemicleading-to-huge-drop-in-air-pollution.

Wilder-Smith, Annelies. Chiew, Calvin. Lee, Vernon. "Can we contain the COVID-19 outbreak with the same measures as for SARS?." Infectious Diseases 20 (5): e102-e107. https://doi.org/10.1016/S1473-3099(20)30129-8.

Xafis, Vicki. Schaefer, G. Owen. Labude, Markus K. Zhu, Yujia. and Hsu, Li Yan. "The Perfect Moral Storm: Diverse Ethical Considerations in the COVID-19 Pandemic." Asian Bioethics Review (12), pp. 65-83, https://doi.org/10.1007/s41649$\underline{020-00125-3}$.

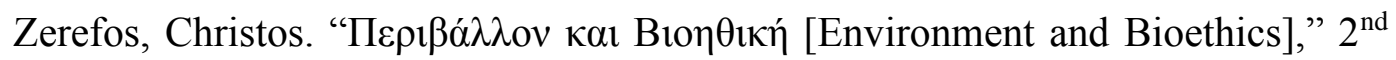
National Conference Greece-Europe 2020: Education, Lifelong Learning, Research, New Technologies and Innovation: Lamia, 2018. https://eproceedings.epublishing.ekt.gr/index.php/inoek/article/view/2441/2265.

Zhang, Ruixiong. Zhang, Yuzhong. Lin, Haipeng. Feng, Xu. Fu, Tzung-May. and Wang, Yuhang. "NOx Emission Reduction and Recovery during COVID-19 in East China." Atmosphere 11 https://doi:10.3390/atmos11040433.

Zimmerman, Michael. "Ecofascism." In Encyclopedia of Religion and Nature, edited by Bron Taylor, 531-532, London: Continuum 2008). 